\title{
KIRMIZI PANCAR UNUNUN GLUTENSİZ BİSKÜVİ ÜRETIMİNDE KULLANILMASI
}

\author{
Hülya GÜL ${ }^{1}$, Fatma HAYIT ${ }^{* 2}$, Bedia ÖZER ${ }^{1}$, Sultan ACUN ${ }^{3}$
}

${ }^{1}$ Süleyman Demirel Üniversitesi, Mühendislik Fakültesi, Gıda Mühendisliği Bölümü, Isparta

${ }^{2}$ Yozgat Bozok Üniversitesi, Boğazlıyan Meslek Yüksekokulu, Gıda İșleme Bölümü, Boğazlıyan, Yozgat

${ }^{3}$ Amasya Üniversitesi. Suluova Meslek Yüksekokulu. Gıda İşleme Bölümü, Suluova, Amasya

\section{Anahtar Kelimeler Glutensiz Bisküvi, Kırmızı Pancar Tozu (KPT), Bisküvi Kalitesi.}

\begin{abstract}
Öz
Glutensiz unlu mamullerin teknolojik ve beslenme kalitesi genellikle düşüktür. Bu nedenle, formülasyonlarında kullanılmak üzere alternatif katkı maddeleri arayıșı halen devam etmektedir. Bu çalışmada, kırmızı pancar tozu (KPT) çölyak diyetini çeşitlendirmek ve zenginleştirmek için glutensiz bisküvi üretiminde kullanılmıştır. Patates nişastası, mısır nişastası, nohut unu, mısır unu ve pirinç unundan hazırlanan glutensiz un formülasyonuna KPT yer değiştirme prensibine göre \%5, 10 ve $\% 15$ oranlarında ilave edilmiştir. 100g glutensiz un formülasyonu ile üretilen bisküviler ise kontrol numunesi olarak kullanılmıştır. Kontrolle karşılaştırıldığında, KPT ilaveli glutensiz bisküvilerin daha yüksek diyet lif, kül ve protein içerdiği belirlenmiştir. \% 15 oranında KPT eklendiğinde, diyet lifi içeriği \% 300 artış göstermiştir. KPT'nin tüm ikame seviyelerindeki glutensiz bisküvi örnekleri, kontrol gruba benzer su aktivitesi, pH ve yağ özellikler göstermiştir. Yayılma oranı, kontrol numunelerine benzer bulunmakla birlikte KPT içeren glutensiz bisküvilerin sertliği önemli ölçüde daha yüksek bulunmuştur. Glutensiz bisküvilerin duyusal değerlendirmesinin sonuçları incelendiğinde KPT ilavesinin bisküvilerde; görünüm, doku, tat, koku ve genel kabul edilebilirlikte önemli bir farka yol açmadığı belirlenmiştir, tüm sonuçlar birlikte değerlendirildiğinde, kabul edilebilir kalitede ve yüksek beslenme özelliğine sahip glutensiz bisküvi üretimi için, formülasyonda \%15 oranına kadar KPT kullanılabileceği sonucuna varılmıștır.
\end{abstract}

\section{USAGE OF RED BEET FLOUR FOR GLUTEN FREE BISCUIT PRODUCTION}

\section{Keywords \\ Gluten-Free Biscuit, Red Beet Powder (RBF), Biscuit Quality.}

\begin{abstract}
Technological and nutritional qualities of gluten-free bakery products are generally low. Therefore, the search for alternative additives for use in their formulations is still ongoing. In this study, red beet flour (RBF) was used to produce gluten-free cookies (GFCs) in order to diversify and enrich celiac diet. The RBF was used to replace, 5, 10 and $15 \mathrm{~g} / 100 \mathrm{~g}$ of gluten free flour formulations (GFF) which is prepared from potato starch, corn starch, chickpea flour, corn flour and rice flour. Cookie from $100 \mathrm{~g} / 100 \mathrm{~g}$ GFF was served as a control sample. As compared to control, GFCs replaced with RBF were showed higher dietary fiber, ash and protein content. When RBF was added at 15\%, the content of dietary fiber was increased by $300 \%$. The spread ratio was found similar to control samples but hardness of RBF containing GFCs were found significantly higher. The results of the sensory evaluation of GFCs were showed that RBF addition was led to no significant difference in appearance, texture, taste, odor, flavor and overall acceptability and a slight decrease in purchasing intent of $15 \% \mathrm{RBF}$ replacement level as evaluated by trained panelists. When all the results are evaluated together, GFCS with acceptable quality and improved nutrition could be prepared from RBF.
\end{abstract}

Alıntı / Cite

Gül, H., Hayıt, F., Özer B., Acun, S., (2021). Kırmızı Pancar Ununun Glutensiz Bisküvi Üretiminde Kullanılması, Mühendislik Bilimleri ve Tasarım Dergisi, 9(4), 1166-1173.

\footnotetext{
*ilgili yazar / Corresponding author: fatma.hayit@bozok.edu.tr, 0 (354) 2903003
} 


\begin{tabular}{l|l|l}
\hline Yazar Kimliği / Author ID (ORCID Number) & \multicolumn{3}{|l}{ Makale Süreci / Article Process } \\
\hline F. Hayıt, 0000-0003-0097-406X & Başvuru Tarihi / Submission Date & 20.04 .2021 \\
H. Gül, 0000-0002-6791-817X & Revizyon Tarihi / Revision Date & 24.08 .2021 \\
B. Özer, 0000-0002-2741-8234 & Kabul Tarihi / Accepted Date & 24.08 .2021 \\
S. Acun, 0000-0003-1954-6102 & Yayım Tarihi / Published Date & 20.12 .2021 \\
\hline
\end{tabular}

\section{Giriş (Introduction)}

Gün geçtikçe farklılaşan tüketim alışkanlıklarına karşılık tahıl ve tahıl ürünleri dünya nüfusunun beslenmesinde önemli bir yer tutmaktadır. Ancak buğday, arpa, tritikale, çavdar, ve yulaf gibi tahıllar ile bu tahıllarla işlenmiş ürünler bağırsak rahatsızlıkları olan bazı insanlar üzerinde sorunlara yol açabilmektedir (Özkaya, 1999). Çölyak hastalığı, gluten içeren gıdaların vücuda alınmasıyla ortaya çıkan bağırsaklarda görülen bir hastalık olmasıyla birlikte (Gren ve Jabri, 2003; İşleroğlu vd., 2009; Villancacci vd., 2011), ayrıca kişilerde çavdar ve arpanın alkolde çözünen proteinleri ve buğday gluteninde bulunan gliadin fraksiyonunun ince bağırsağın mukozasında hasara neden olduğu bir sendrom (Fasano ve Catassi, 2001) olarak da tanımlanmaktadır. Gluten, unlu mamüllerin ana kalitesi ve yapısı üzerinde önemli olan özellikle buğdayda bulunan proteindir (Alvarenga vd., 2011). Buğday bu yüzden çölyak hastalığı için en alerjik proteine sahip olan tahıl ürünüdür (Nehra vd., 2013). İçeriğinde gluten bulunduran buğday ve buğday ürünlerinin yanı sıra, gliadin homoloğu olan prolaminleri içeren, çavdar, tritikale ve arpa ürünleri de çölyak hastalarında aynı rahatsızlığın oluşmasına neden olabilmektedir (Türksoy ve Özkaya, 2006).

Glutensiz gıdalar çölyak hastaları yanında gluten duyarlılığından rahatsız bireyler ya da yaşam tarzıyla glutensiz diyete yönelen kişiler için de gereklidir (Masure vd., 2016). Ekonomik ve teknolojik gelişmelere koşut olarak, gıda ürünlerinin çeşitlendirilmesi ve niteliklerinin, damak zevki veya sağlığa uygunluk açısından, geliştirilip iyileștirilme çalışmaları da yoğunluk kazanmaktadır (Sanchez ve Osella, 2002).

Kırmızı pancar (Beta vulgaris), Amaranthaceace ailesinde yer alan çiçekli bir bitkidir. Kırmızı pancarın ana vatanı Avrupa'nın kuzeyi ve güneyidir. Ülkemizde ise en çok üretim ve tüketim Ege ve Marmara bölgelerinde olmaktadır (Tomar ve Yıldırım, 2019). Kırmızı pancar, önemli antioksidan özelliklere sahip betalain (Azeredo, 2009) adı verilen toz haline getirilerek, gıdalarda renklendirici (E 162) olarak kullanılan (Georgiev vd., 2010) renk pigmenti yönünden oldukça zengin bir üründür (Pavlov vd., 2002). Ayrıca B vitaminleri (B1, B2, B3, B6) ve özellikle folik asit açısından oldukça zengin bir kaynaktır (Maria vd., 2012) Çölyak hastaları için üretilen ürünler özellikle nişasta bazlı olduğu için bu ürünlerin diyet lif, mineral madde ve protein açısından besin değerleri yüksek gıda ürünleri ile zenginleștirilmesi gerekmektedir (Hayit, 2018).

$\mathrm{Bu}$ çalışmada çölyak hastalarının diyetlerini çeşitlendirmek ve zenginleştirmek amacıyla kırmızı pancar unu katkılı glutensiz bisküvi üretimi amaçlanmıştır. Kırmızı pancar unu protein, diyet lif, vitamin ve mineralce zengin, fonksiyonel bir üründür. Bu ürün farklı oranlarda (\%0, \%5, \%10 ve \%15) yer değiștirme prensibine göre glutensiz bisküvi formülasyonuna ilave edilmiştir. Üretilen bisküvilerin bazı fiziksel, kimyasal, tekstürel ve duyusal analizleri yapılarak bisküvi kalitesi incelenmiştir.

\section{Materyal ve Yöntem (Material and Method)}

\subsection{Materyal (Material)}

Kırmızı pancar unu (KPU): Kurutularak öğütülüp toz formatına getirilmiş KPT Kurucum Gıda (Isparta)'dan temin edilmiştir. Glutensiz bisküvi üretiminde kullanılan bileşenlerden mısır ve pirinç unları, patates ve mısır nişastaları ile ksantam gam (İzmir) Demeter Kimya'dan satın alınmıștır. Pudra şekeri, bitkisel yağ (shortening) ve kabartma tozu (sodyum bikarbonat) Uğur Gıda (Isparta)'dan, mısır şurubu (HFCS \%42) Sunar Mısır Entegre Tesisleri San. ve Tic. A.Ş., (Adana) temin edilmiştir. Çalışmada Süleyman Demirel Üniversitesi Tahıl İşleme Teknolojisi Laboratuvarı çeşme suyu kullanılmıştır. Formülasyonda kullanılan tuz TS 933, TSE, 1986, Yemeklik Tuz standardına uygun olacak şekilde piyasadan temin edilmiştir.

\subsection{Yöntem (Method)}

\subsubsection{Deneme planı (Trial plan)}

Glutensiz bisküvi üretiminde KPU \%0, \%5, \%10 ve \%15 oranlarında (ilave edilecek miktarlar ön denemeler ile belirlenmiştir) bisküvi formülasyonuna ilave edilmiştir. Pancar tozu ilave edilmeden üretilen bisküvi örnekleri kontrol grubu bisküviler olarak kullanılmıştır. Glutensiz bisküvi üretiminde kullanılan glutensiz un karışımı Hayıt ve Gül (2017) tarafından yapılan bir çalışmada optimizasyon \%7 mısır nişastası, \%8 mısır unu, \%40 pirinç unu ve 
\%45 patates nişastası olarak belirlenmiş ve, aynı formülasyon bu çalıșmada da glutensiz un karışımı olarak kullanılmıştır. Tüm denemeler 3 tekerrür olacak şekilde gerçekleștirilmiştir.

\subsubsection{Bisküvi üretimi (Biscuit production)}

Glutensiz bisküvi üretimi için AACC Metot 10-50.05 kullanılmıștır. AACC Metot 10-50.05'e göre bisküvi yapımında kullanılan formülasyon Tablo 1'de verilmiştir.

Tablo 1. Bisküvi üretiminde kullanılan bisküvi formülasyonu (Biscuit formulation used in biscuit production)

\begin{tabular}{ll}
\hline Bileşen & Miktar (gram) \\
\hline Shortening & 64.0 \\
Pudra şekeri & 130.0 \\
Tuz & 2.1 \\
Sodyum bikarbonat & 2.5 \\
Dekstroz Çözeltisi & 33 \\
Destile Su & 16.0 \\
Glutensiz un karışımı & 225 \\
\hline
\end{tabular}

Hayıt ve Gül (2017) tarafından optimizasyon çalışması ile belirlenmiş glutensiz un karışımına yer değiștirme prensibine göre $\% 0, \% 5, \% 10$ ve $\% 15$ oranlarında deneme planında belirtilen KPU gruplarının her biri ayrı ayrı ilave edilerek un karışımı hazırlanmıştır. Bisküvi hamurlarının yoğurma işlemi mikserde (Hobart mikser N50, Almanya) AACC Metot 10-50.05'e göre yapılmıştır. Yoğurma işlemi tamamlanan hamurlar çapı 5.7-7.0 mm arasında olan tahta oklava ile $5 \mathrm{~mm}$ kalınlığında olacak şekilde inceltilmiș ve iç çapı $60 \mathrm{~mm}$ olan bisküvi kesme aparatı ile yuvarlak bir şekilde kesilmiștir. Bisküviler $205^{\circ} \mathrm{C}^{\prime}$ de konveksiyonel firında (Fimak FSET4, Türkiye) 10 dakika süreyle pişirilmiştir. (Pişirme işlemi sırasında uygulanan sıcaklık ve süre normları yapılan ön denemeler sonucunda belirlenmiștir).

\subsubsection{Pancar tozunda yapılan analizler (Analyses of beet powder)}

Kurutulmuş KPU örneklerinde; nem (AACC Method, 44-01.01, 2000), kül (AACC Method, 08-01.01, 2000), toplam diyet lif (AACC Method, 32-07.01, 2000), renk değerinin belirlenmesi (Larrauri vd., 1997), soxhalet yağ tayin cihazı ile yağ tayini (AOAC, 1990), Ph ölçümü (Anonima, 1991), su aktivitesi ölçümü (Novasina, Lab Touch-aw, Lanchen, İsviçre) analizleri yapılmıştır.

\subsubsection{Bisküvilerde yapılan analizler (Analyses of biscuits)}

\subsubsection{Fiziksel analizler (Physical analyses)}

Bisküvilerin fiziksel kalite parametrelerini belirlemek amacıyla (her denemede en az 6 bisküvi örneği analize alınmıştır) üretilen bisküvilerin çap ve kalınlık değerleri dijital mikrometre kullanılarak (her örnekte en az 4 bölgeden) ölçülmüştür. Yayılma oranı bisküvi çapının kalınlığına oranlanması ile hesaplanmıştır (AACC Method, 10-50D).

\subsubsection{Kimyasal analizler (Chemical analyses)}

Bisküvilerin kimyasal kalite özelliklerini belirlemek amaciyla bisküvilerde, nem (AACC Method, 44-01.01, 2000), kül (AACC Method, 08-01.01, 2000), protein (AACC Method, 46-30. 01, 2000), yağ (AOAC, 1990), toplam diyet lif (AACC Method, 32-07.01, 2000), pH ölçümü (Anonim, 1991), su aktivitesi ölçümü (Novasina, Lab Touch-aw, Lachen, İsviçre) analizleri yapılmıştır.

\subsubsection{Tekstürel analiz (Textural analyses)}

Tekstür analiz cihazında (TA-XT2, Stable Micro Systems, Surrey, İngiltere) üç noktalı bükme probu ve 30 kg'lık yük hücresi kullanılarak glutensiz bisküvi örneklerinin sertlik değerleri pişirme işleminden 6 saat sonra belirlenmiștir (her denemede 6 bisküvi örneği alınmıştır). Tekstür analiz cihazında test parametreleri; ön test hızı: $1.0 \mathrm{~mm} / \mathrm{s}$, test hızı: $3.0 \mathrm{~mm} / \mathrm{s}$, son test hızı: $10 \mathrm{~mm} / \mathrm{s}$, uzaklık $5.0 \mathrm{~mm}$ ve veri alma hızı 500 pps. olarak ayarlanmıștır. 


\subsubsection{Renk analizi (Color analysis)}

Renk ölçümü Konica Minolta (Minolta CR-410, Minolta Co Ltd., Tokyo, Japonya) renk ölçüm cihazı ile yapılmıştır. Renk skalası; L değeri [(0)Siyah - (100) Beyaz], a değeri [(+) kırmızı, (-) yeşil] ve b değeri [(+) sarı, (-) mavi] olarak kullanılmıştır.

\subsubsection{Duyusal analiz (Sensory analysis)}

Bisküviler 15 kişilik eğitimli bir panelist grubu tarafından değerlendirilmiştir. Duyusal değerlendirmeye başlamadan önce panelistlere bisküvilerin duyusal değerlendirme kriterleri hakkında bilgi verilmiş ve ön denemeler yapılmıştır. Rastgele numaralandırılan numuneler analize katılan panelistlere ayrı ayrı sunulmuş, bir örnekten diğerine geçerken panelistlere soğuk su verilmiştir. Bisküviler yüzey görünüm özellikleri (parlaklıkmatlık, renk, yüzey düzgünlüğü), kesit özellikleri (kesit yapısı: sıkı-compakt yapı, gözenek dağılımı, kabuk inceliği, kesit rengi: iç renk, kabuk iç renk farkı), tadım özellikleri ve satın alınabilirlik açısından duyusal değerlendirme metodu kullanılarak (Lawless and Heymann, 2010) değerlendirmeye tabi tutulmuştur. Duyusal kalite kriterleri 1"den 5"e kadar puanlama sistemine göre yapılmıştır (5 puan: çok iyi, 4 puan: iyi, 3 puan: kabul edilebilir, 2 puan: yeterli değil, 1 puan: kötü).

\subsubsection{6 İstatistiksel analiz (Statistical analysis)}

Denemelerde farklı oranlarda KPT ilave edilerek üretilen bisküvilerin ölçülen tüm özelliklerinden elde edilen verilerin ANOVA ve Duncan testleri yapılmıştır. Analizler için SPSS 22.0 (Versiyon 22) istatistik paket programından faydalanılmış ve analiz tesadüf parsellerinde 3 faktörlü deneme desenine göre yapılmıştır.

\section{Deneysel Sonuçlar ve Tartışma (Experimental and Discussion)}

\subsection{Glutensiz unların kimyasal ve renk özellikleri (Chemical and color properties of gluten-free flours)}

Glutensiz unların kimyasal ve renk özellikleri Tablo 2'de verilmiștir. Tablo incelendiğinde KPT'nin yüksek oranda kül ve diyet lif içerdiği görülmektedir. Tablo 2' de verilen bilgilere paralel olarak mısır nişastası, patates nişastası, pirinç unu ve mısır unu için farklı çalışma sonuçlarıyla paralellik görülmektedir (Wu ve Miano, 2008; Yarpuz, 2011; Ali vd., 2014; Hatipoğlu, 2016; Turkut vd., 2016; Giuberti vd., 2018).

Tablo 2. Glutensiz unların kimyasal ve renk özellikleri (Chemical and color properties of gluten-free flours)

\begin{tabular}{|c|c|c|c|c|c|c|c|c|}
\hline ORAN & $\operatorname{Nem}(\%)$ & $\begin{array}{l}\text { Kül } \\
(\%)\end{array}$ & $\begin{array}{c}\text { Diyet lif } \\
(\%)\end{array}$ & $\mathrm{L}$ & $\mathrm{a}$ & $\mathrm{b}$ & aw & $\mathrm{pH}$ \\
\hline Kırmızı pancar tozu & $5.11^{\mathrm{c}}$ & $7.12^{\mathrm{a}}$ & $63.2^{\mathrm{a}}$ & $45.68^{c}$ & $14.26^{\mathrm{a}}$ & $6.82^{b}$ & $0.45^{a}$ & $5.5^{c}$ \\
\hline Mısır nişastası & $8.34^{b}$ & $0.69 \mathrm{c}$ & $0.47 \mathrm{e}$ & $95.34^{\mathrm{a}}$ & $-0.95^{c}$ & $5.20^{c}$ & $0.48^{\mathrm{a}}$ & $7.90^{\mathrm{b}}$ \\
\hline Patates nișastası & $8.3^{b}$ & $0.79 c$ & $0.69 \mathrm{~d}$ & $93.34^{\mathrm{a}}$ & $-0.10^{c}$ & $6.53^{\mathrm{b}}$ & $0.42^{\mathrm{a}}$ & $7.90^{\mathrm{b}}$ \\
\hline Pirinç unu & $9.29 \mathrm{a}$ & $0.47^{d}$ & $4.88^{\mathrm{c}}$ & $89.69^{b}$ & $0.25^{b}$ & $6.53^{b}$ & $0.43^{a}$ & $8.10^{\mathrm{a}}$ \\
\hline Misir unu & $9.1^{\mathrm{a}}$ & $1.12^{\mathrm{b}}$ & $9.16^{\mathrm{b}}$ & $82.80^{b}$ & $0.48^{b}$ & $23.3^{\mathrm{a}}$ & $0.46^{\mathrm{a}}$ & $7.90^{\mathrm{b}}$ \\
\hline
\end{tabular}

Tablo 2'de KPT'nin diğer glutensiz un formülasyonunda kullanılacak bileşenlere göre L değerinin (parlaklık) daha düşük olduğu yani daha koyu olduğu, a ve b değerlerinin ise daha yüksek olduğu görülmektedir. Genel olarak daha koyu-kırmızı renkli olduğu görülmektedir.

\subsection{Glutensiz bisküvilerin fiziksel özellikleri (Physical properties of gluten free biscuits)}

Denemede üretilen bisküvilerin çap ve kalınlık değerleri ve yayılma oranı ölçüm sonuçları Tablo 3'de verilmiştir. Çap, kalınlık ve yayılma oranı değerlerinden çapı geniş, yayılması yüksek ve kalınlığı düşük bisküviler bisküvi kalitesi açısından tercih edilmektedir (Kissell vd.,1971). Yapılan normal bisküvi çalışmalarında çap değerinin 51.20-81,79 mm; kalınlık değerinin 3.90-13.55 mm; yayılma oranının 6.03-11.80 aralığında olduğu görülmektedir (Gürsu vd., 1997; Tüksoy, 2011; Beğen, 2012; Demir, 2019). Glutensiz bisküvilerin yayılma oranı ise 17.35-52.43; çapları 51.08-58.15 mm; kalınlık 2.92-9.80 mm aralığında olduğu bildirilmiştir (Doğan, 2016; Tüter, 2019). 
Tablo 3. Glutensiz bisküvilerin fiziksel özellikleri (Physical properties of gluten free biscuits)

\begin{tabular}{llll}
\hline ORAN & $\begin{array}{lll}\text { Cap } \\
(\mathrm{mm})\end{array}$ & $\begin{array}{l}\text { Kalınlık } \\
(\mathrm{mm})\end{array}$ & Yayılma Oranı (Çap/Kalınlık) \\
\hline Kontrol & $66.94^{\mathrm{a}^{*}}$ & $10.93^{\mathrm{a}}$ & $23.48^{\mathrm{a}}$ \\
$5 \%$ & $66.42^{\mathrm{a}}$ & $10.50^{\mathrm{a}}$ & $22.99^{\mathrm{a}}$ \\
$10 \%$ & $65.26^{\mathrm{ab}}$ & $10.69^{\mathrm{a}}$ & $22.54^{\mathrm{a}}$ \\
$15 \%$ & $63.19^{\mathrm{b}}$ & $10.30^{\mathrm{a}}$ & $23.04^{\mathrm{a}}$ \\
\hline \hline
\end{tabular}

Çap ve kalınlık değerleri literatür çalışmalarına benzerlik gösterirken; yayılma oranı glutensiz bisküvi örneklerinde, normal buğday unu ile yapılan bisküvi örneklerine göre yüksek çıkmıștır. Farklı çalıșmalarda formülasyona lifli bir ürün ilavesinin yayılma oranını azalttı̆̆ı (Türksoy ve Özkaya, 2011; Öztürk ve Özboy, 2002); buğday ve pirinç lifi ilavesi ile kalınlığın azaldığı, arpa ve yulaf lifi ilavesiyle arttığı bildirilmiştir (Sudha vd., 2007). Lif ilavesinin fiziksel özellik üzerinde, farklı çalışmalarda farklı sonuçlar verdiği görülmektedir. Bu çalışmada ise KPT ilavesinin kalınlık ve yayılma oranı üzerinde istatistiksel bir etkisi olmazken, bisküvi çaplarının azalmasına neden olmuștur.

\subsection{Glutensiz bisküvilerin kimyasal özellikleri (Chemical properties of gluten free biscuits)}

Denemede üretilen bisküvilerin nem, aw, pH, diyetlif, yağ, protein ve kül değerleri Tablo 4'te verilmiștir. Tablo 4'e göre en düşük nem \%5 KPT ilaveli bisküvi örneğinde ölçülürken, en yüksek nem miktarı \%15 oranında KPT ilave edilen örnekte gözlemlenmiştir. KPT’nin oranı arttıkça su aktivitesinin artmasına bağlı olarak nem değerlerinin de kontrol grubu bisküvi örneklerine göre artış gösterdiği tespit edilmiştir. Su aktivitesi, pH, yağ ve protein değerleri incelendiğinde glutensiz un karışımına KPT ilavesinin bu değerler üzerinde istatistiksel olarak etkili olmadığı görülmüştür. KPT yüksek oranda diyet lif ve kül içeriğine sahip olduğu için glutensiz un formülasyonuna eklenmesi ile birlikte deneme ürünlerin diyet lif ve kül içeriklerini ilave yüzdelerine paralel arttırmıștır. \%15 oranında KPT kullanımı ile glutensiz bisküvilerin diyet lif içeriği kontrol grubuna göre \%192 oranında, kül içeriği ise \%121 oranında artmıştır. Benzer olarak yapılan bir çalışmada KPT ilaveli kek örneklerinde protein, diyet lif ve kül içeriklerinin KPT kullanımına bağlı olarak arttığı bildirilmiștir. Aynı çalıșmada kek örneklerinde yağ içeriğinin de \%23.5'den \%29.4'e çıktığı belirtilmiștir (Pinki ve Awasthi, 2014). Aksi olarak bu çalıșmada KPT ilavesinin örneklerin yağ değeri üzerinde istatistiki bir etkisi olmadığı görülmektedir. Yine benzer bir sonuç olarak; Lisiecka ve Wójtowicz, (2021) tarafından yapılan çalışmada ise; kızartılmış atıştırmalık ürünlerde taze kırmızı pancar küspesi kullanımı ile ürünlerin protein, kül ve toplam diyet lif içeriklerinin arttığı bildirilmiştir.

Tablo 4. Glutensiz bisküvilerin kimyasal özellikleri (Chemical properties of gluten free biscuits)

\begin{tabular}{|c|c|c|c|c|c|c|c|}
\hline Oran & $\begin{array}{c}\text { Nem } \\
(\%)\end{array}$ & aw & $\mathrm{pH}$ & $\begin{array}{c}\text { Diyet lif } \\
(\%)\end{array}$ & $\begin{array}{l}\text { Yağ } \\
(\%)\end{array}$ & $\begin{array}{c}\text { Protein } \\
(\%)\end{array}$ & $\begin{array}{l}\text { Kül } \\
(\%)\end{array}$ \\
\hline Kontrol & $7.27^{\mathrm{b}}$ & $0.42^{\mathrm{a}}$ & $7.21^{\mathrm{a}}$ & $2.13^{\mathrm{d}}$ & $15.49^{a}$ & $9.50^{\mathrm{b}}$ & $0.82^{d}$ \\
\hline$\% 5$ & $6.62^{c}$ & $0.36^{a}$ & $7.10^{a}$ & $3.84^{c}$ & $15.27^{a}$ & $11.12^{b}$ & $1.09 \mathrm{c}$ \\
\hline$\% 10$ & $9.02^{\mathrm{a}}$ & $0.40^{a}$ & $7.25^{a}$ & $5.06^{b}$ & $15.28^{a}$ & $11.25^{b}$ & $1.45^{b}$ \\
\hline$\% 15$ & $9.84^{\mathrm{a}}$ & $0.40^{a}$ & $7.20^{a}$ & $6.23^{a}$ & $15.30^{a}$ & $11.20^{\mathrm{b}}$ & $1.82^{\mathrm{a}}$ \\
\hline
\end{tabular}

KPT kullanımı ile örneklerin diyet lif içeriği ile birlikte kül içeriğide artmıştır benzer olarak Levent (2005) tarafından yapılan çalışmada diyet lif içeriğinin artmasına paralel olarak kül miktarının da arttığı bildirilmiştir.

\subsection{Glutensiz bisküvilerin tekstürel özellikleri (Textural properties of gluten free biscuits)}

Denemede üretilen bisküvilerin sertlik ve kırılganlık değerleri Tablo 5'te verilmiştir. Tabloya göre glutensiz un karıșımına KPT ilave edilmesi sertlik değerinin artmasına sebep olmuștur. Benzer olarak șeker pancarı lifi kullanılan bir çalıșmada șeker pancarı lifi ile bisküvilerin sertlik değerinin arttığı bildirilmiștir (Özboy ve Köksel, 1997). Kırılganlık değeri için KPT’nin glutensiz un formülasyonuna eklenmesi istatistiki bir fark oluşturmamıştır. 
Tablo 5. Glutensiz bisküvilerin tekstürel özellikleri (Textural properties of gluten free biscuits)

\begin{tabular}{llc}
\hline Oran & Sertlik (g) & Kirllganllk \\
\hline Kontrol & $5694.02^{\mathrm{b}^{*}}$ & $41.45^{\mathrm{a}}$ \\
$5 \%$ & $6198.23^{\mathrm{a}}$ & $39.50^{\mathrm{b}}$ \\
$10 \%$ & $6928.49^{\mathrm{a}}$ & $40.91^{\mathrm{a}}$ \\
$15 \%$ & $6381.35^{\mathrm{a}}$ & $41.03^{\mathrm{a}}$ \\
\hline \hline
\end{tabular}

* : Aynı sütunda farklı harfler arasındaki farklılıklar önemlidir $(\mathrm{P}<0.01)$

İncelenen literatür çalışmalarında bisküvilerin sertlik değerinin 318.46 - 8498.89 (g) aralığında; kırılganlık değerinin ise 4.90-5.25 aralığında olduğu görülmektedir (Taş, 2011; Doğan, 2016; Hayıt ve Gül, 2019; Tüter, 2019). Litaratürde incelenen tekstür değerlerinin çok geniş aralıkta olmasının sebebinin formülasyonda kullanılan maddelerin ve kullanılan miktarlarının tüm çalıșmalarda farklı olmasından kaynaklandığı düșünülmektedir. Sertlik değeri kullanılan su miktarından dahi etkilenen önemli bir kalite parametresidir (Martinez vd., 2018). Yapılan çalışmalarda sertlik değerinin oldukça farklı çıkması bu özelliğinden dolayı beklenen bir durumdur.

\subsection{Glutensiz bisküvilerin duyusal özellikleri (Sensory properties of gluten-free biscuits)}

Denemede üretilen bisküvilerin duyusal özellikleri Tablo 6'de verilmiştir. Koku, ağızda dağılım, kuru kumlu olma, gevreklik, yüzey rengi, yüzey düzgünlüğü, yüzey parlaklığı, kabul edilebilirlik, sertlik, satın alınabilirlik parametreleri için kontrol grupla KPT eklenen örnekler arasında istatistiki bir fark olmadığı görülmüștür.

Tablo 6. Glutensiz bisküvilerin duyusal özellikleri (Sensory properties of gluten-free biscuits)

\begin{tabular}{|c|c|c|c|c|c|c|c|c|c|c|c|c|}
\hline $\begin{array}{l}\text { Bisküvi } \\
\text { örneği } \\
\end{array}$ & Koku & Aroma & Tat & Ağızda dağılım & $\begin{array}{c}\text { Kuru kumlu } \\
\text { olma }\end{array}$ & Gevreklik & $\begin{array}{l}\text { Yüzey } \\
\text { rengi }\end{array}$ & $\begin{array}{c}\text { Yüzey } \\
\text { düzgünlügü }\end{array}$ & $\begin{array}{c}\text { Yüzey } \\
\text { parlaklığg }\end{array}$ & $\begin{array}{c}\text { Kabul } \\
\text { edilebilirlik }\end{array}$ & Sertlik & $\begin{array}{c}\text { Satın } \\
\text { alınabilirlik }\end{array}$ \\
\hline Kontrol & $4.33^{\mathrm{a}^{*}}$ & $4.66^{\mathrm{a}}$ & $4.66^{\mathrm{a}}$ & $4.33^{\mathrm{a}}$ & $4.33^{\mathrm{a}}$ & $4.33^{\mathrm{a}}$ & $4.33^{\mathrm{a}}$ & $4.33^{\mathrm{a}}$ & $5.00^{\mathrm{a}}$ & $5.00^{\mathrm{a}}$ & $4.83^{\mathrm{a}}$ & $4.33^{\mathrm{a}}$ \\
\hline $5 \%$ & $4.00^{\mathrm{a}}$ & $3.83^{\mathrm{b}}$ & $3.83^{b}$ & $3.66^{\mathrm{a}}$ & $3.66^{\mathrm{a}}$ & $3.66^{\mathrm{a}}$ & $3.83^{\mathrm{a}}$ & $3.83^{\mathrm{a}}$ & $4.33^{\mathrm{a}}$ & $5.00^{\mathrm{a}}$ & $3.83^{\mathrm{a}}$ & $4.50^{\mathrm{a}}$ \\
\hline $10 \%$ & $3.88^{\mathrm{a}}$ & $3.50^{\mathrm{b}}$ & $3.66^{b}$ & $4.00^{\mathrm{a}}$ & $3.66^{\mathrm{a}}$ & $3.50^{\mathrm{a}}$ & $4.00^{\mathrm{a}}$ & $3.66^{\mathrm{a}}$ & $4.16^{\mathrm{a}}$ & $5.00^{\mathrm{a}}$ & $4.00^{\mathrm{a}}$ & $4.33^{\mathrm{a}}$ \\
\hline $15 \%$ & $4.00^{\mathrm{a}}$ & $4.50^{\mathrm{a}}$ & $4.50^{\mathrm{a}}$ & $3.83^{\mathrm{a}}$ & $3.83^{\mathrm{a}}$ & $3.83^{\mathrm{a}}$ & $4.50^{\mathrm{a}}$ & $3.50^{\mathrm{a}}$ & $4.00^{\mathrm{a}}$ & $5.00^{\mathrm{a}}$ & $4.33^{\mathrm{a}}$ & $4.00^{\mathrm{a}}$ \\
\hline
\end{tabular}

*: Aynı sütunda farklı harfler arasındaki farklılıklar önemlidir $(\mathrm{P}<0.01)$

Satın alınabilirlik için glutensiz bisküvilere \%15’e kadar KPT ilave edilebileceği belirlenmiştir. Benzer olarak \%20 oranında KPT'nin keke ilave edildiği bir çalışmada panelistlerin bu ürünü duyusal olarak çok beğendiği bildirilmiştir (Pinki ve Awasthi, 2014). Formülasyona KPT ilavesi ile ürünün diyet lif içeriği arttırılmış bununla beraber duyusal değerlendirilmesinde olumsuzluk olmamıștır. Literatürde benzer çalışmalar da bulunmaktadır. Chaidet, (2007) tarafindan havuç lifi kullanılarak üretilen bisküvilerin duyusal değerlendirilmesinde kontrol grup örneklere göre kabul edilebilirlik değerinde bir fark belirlenmemiștir. Yine başka bir çalışmada; balkabağı lifi kullanılarak üretilen noodlelarda \%5 e kadar lif ilavesinin duyusal değerlendirme sonucunda fark oluşturmadığı bildirilmiştir (Lee vd., 2002). Formülasyona lif içeriğine sahip farklı bir ürün ilavesinin duyusal açıdan sorun oluşturmadığı görülmektedir.

\section{Sonuç (Result)}

Çalıșmada glutensiz bisküvilerinin besin değeri ve kalitesinin arttırılması için formülasyonda farklı oranlarda (\%5, \%10 ve \%15) KPT kullanılarak üretimler yapılmıştır. KPT ilavesi ile glutensiz bisküvilerin fiziksel ve tekstürel özelliklerinde KPT’nın kullanımına bağlı herhangi bir olumsuzluk olmadığı görülmüştür. Kimyasal özellikleri incelendiğinde glutensiz bisküvilerin besinsel özelliklerini geliştirdiği belirlenmiştir. Duyusal özellikleri incelendiğinde ise panelistler tarafından kabul gördüğü belirlenmiştir. Çalışma sonucunda KPT'nun glutensiz un formülasyonunda \%15 oranına kadar kullanılabilir olduğu belirlenmiştir.

\section{Teşekkür (Acknowledgement)}

Bu çalışma TÜBİTAK_BİDEB_ 2209-B - Sanayiye Yönelik Lisans Bitirme Tezi Destekleme Programı kapsamında desteklenmiştir. Desteklerinden dolayı TÜBİTAK'a teşekkür ederiz. Ayrıca bu çalışma uluslararası ICAFOF-2018 (International Conference on Agriculture, Forest, Food Sciences and Technologies) konferansında sözlü sunum olarak sunulmuş ve bildiri kitapçığında özet bildiri olarak basılmıştır. 


\section{Çıkar Çatışması (Conflict of Interest)}

Yazarlar tarafından herhangi bir çıkar çatışması beyan edilmemiştir. No conflict of interest was declared by the authors.

\section{Kaynaklar (References)}

AACC, 2000. International. Approved Methods of Analysis, 11th Ed. AACC International, St. Paul, MN, U.S.A.

Ali, A., Wani, T.A., Wani, A.I, Masoodi, F.A., 2014. Comparative Study of the Physico-chemical Properties of Rice and Corn Starches Grown in Indian Temperate Climate. Journal of the Saudi Society of Agricultural Sciences, 15, 75-82.

Alvarenga, N., Lion F., Belga, E., Motrena, P., Guerreiro, S., Carvalho, J., Canada, H., 2011. Characterization of Gluten -free Bread Prepared From Maize, Rice and Tapioca Flours Using the Hydrocolloid Seaweed Agar-Agar. Recent Research in Science and Technology, 3, 64-68.

Azeredo, 2009. H.M.C. AzeredoBetalains: Properties, sources, applications and stability - A review, International Journal of Science \& Technology, 44 (2009), pp. 2365-2376.

Beğen, F., 2012. Yüksek lif içerikli bisküvi üretiminde lüpen (Lupinus albus L.) kepeği kullanımı üzerine bir araştırma. Selçuk Üniversitesi Fen Bilimleri Enstitüsü, Yüksek Lisans Tezi.

Chaidet, T., 2007. The study of extraction of dietary fiber and carotenoids from carrot pomace, Master Thesis (unpublished), Food and Nutrition for Development, Faculty Graduate Studies, Mahidol University.

Demir, K.M., 2019. Bisküvi Üretiminde Tam Buğday Unu ve Paçallarının Kullanımı. Tarım Bilimleri Dergisi, 21, 100-107.

Doğan, H., 2016. Glutenli Ve Glutensiz Bisküvi Üretiminde Fonksiyonel Bir Bileșen Olarak Ușkun Kullanımı. Yüzüncü Yıl Üniversitesi Fen Bilimleri Enstitüsü, Yüksek Lisans Tezi

Fasano, A., Catassi C, 2001. Current Approaches to Diagnosis and Treatment of Celiac Disease: an Evolving Spectrum. Gastroenterology, 120, 36-51.

Georgiev, V., Weber, J., Kneschke, E., Denev, P.N., Bley, T., Pavlov, A. I., 2010. Antioxidant Activity and Phenolic Content of Betalain Extracts from Intact Plants and Hairy Root Cultures of the Red Beetroot Beta vulgaris cv. Detroit Dark Red. Plant Foods for Human Nutrition, 65, 105-111.

Giuberti, G., Rocchetti, G., Sigolo, S., Fortunati, P., Lucini, L., Gallo, A., 2018. Exploitation of Alfalfa Seed (Medicago sativa L.) Flour into Gluten-Free Rice Cookies: Nutritional, Antioxidant and Quality Characteristics. Food Chemistry, 239, 679-687.

Gren, P., Jabri, B., 2003. Coeliac Disease. Lancet, 362, 383-391.

Gürsu, Ö., Ercan, R., Denli, E., 1997.Soya unu katkısının bisküvi kalitesine ve raf ömrüne etkisi. Gıda, 22,95-103.

Hatipoğlu, S., 2016. Patates Unu ve Gam İlavesinin Glutensiz Ekmek Kalitesi Üzerine Etkileri. Pamukkale Üniversitesi Fen Bilimleri Enstitüsü, Yüksek Lisans tezi.

Hayıt, F., 2018. Çölyak Hastalarına Yönelik Kısmi Pişirilerek Dondurma Yöntemi İle Glutensiz Ekmek Üretimi Ve Kalitesinin Araştırılması. Süleyman Demirel Üniversitesi Fen Bilimleri Enstitüsü, Doktora tezi.

Hayıt, F., Gül, H., 2018. Optimization of Gluten Free Cookie Flour by Using Response Surface Methodology, 1st International Symposium on Innovative Approaches in Scientific Studies, Antalya, Türkiye, 11-13 Nisan 2018, pp.81-81.

İşleroğlu, H., Dirim, S., Ertekin, F., 2009. Gluten İçermeyen, Hububat Esaslı Alternatif Ürün Formülasyonları ve Üretim Teknolojileri. Gida, 34, 29-36.

Kissell, L.T., Pomeranz, Y., Yamazaki, W.T., 1971. Effects of flour lipids on cookie quality. Cereal Chemistry, 48, 655-662.

Lawless, H.T., Heymann, H., 2010. Sensory evaluation of food principles and practises, descriptive analysis (2nd ed.). Gaithersburg: Chapman \& Hall/Aspen Publishers, Inc.

Lee, C., Cho, J.K., Lee, S.J., Koh, W., Park, W., Kim, C.H., 2002. Enhancing ßcarotene content in Asian noodles by adding pumpkin powder. Cereal Chemistry, 79 (4), 593-595.

Lisiecka, K., Wójtowicz, A., 2021. Effect Of Fresh Beetroot Application And Processıng Conditıons On Some Quality Features Of New Type Of Potato-Based Snacks. Food Science and Technology, 0023-6438(21)00072-4.

Maria, E., Latorre, P.R., Bonelli, A.M., Rojas, L.N., Gerschenson., 2012. Microwave inactivation of red beet (Beta vulgaris L. var. conditiva) peroxidase and polyphenoloxidase and the effect of radiation on vegetable tissue quality. Journal of Food Engineering. 109:676- 684.

Martinez, M.M., Román, L., Gomez, M., 2018. Implications of Hydration Depletion in the in Vitro Starch Digestibility of White Bread Crumb and Crust. Food Chemistry, 239, 295-303.

Masure, H.G., Fierens, E., Delcour, J.A., 2016. Current and Forward Looking Experimental Approaches in Gluten-Free Bread Making Research. Journal of Cereal Science, 67, 92-111.

Nehra, V., Marietta, E., Murray, J., 2013. Celiac Disease. Encyclopedia of Human Nutrition, 298-306.

Özboy, Ö., Köksel, H., 1997. Besinsel liflerin bisküvi üretiminde kullanımı. 2. Un, Bulgur ve Bisküvi Sempozyumu, pp 183-193, 28-30 Mayıs, Karaman.

Özkaya, B., 1999. Tahılların neden olduğu alerjiler ve önemi-2, Food Hi- TECH, Mar. 82-88.

Öztürk, S., Özboy, O., Cavidoğlu, İ., Köksel, H., 2002. Effects of brewers spent grain on quality and dietary fiber content cookies, J. Inst. of Brew., 108.1, 23-27.

Pavlov, A., Kovatcheva, P., Georgiev, V., Koleva, I., Ilieva, M., 2002. Biosynthesis and Radical Scavenging Activity of Betalains During The Cultivation of Red Beet (Beta vulgaris) Hairy Root Cultures. Z. Naturforsch, 57, 640-644.

Pinki, B., Pratima, A., 2014. Sensory and nutritional evaluation of value added cakes formulated by incorporating beetroot powder. International Journal of Food and Nutritional Sciences 3(6):145-148.

Sanchez, H. D., Osella, C.A., Torre, M.A., 2002 Optimization of gluten free bread prepared from corn starch, rice flour, and cassava starch, Jouynal of FoofScience, 67-1.

Sudha, M.L., Vetrimani, R., Leelavathi, K., 2007. Influence of fibre from different cereals on the rheological characteristics of wheat flour dough and on biscuit quality. Food Chem.100 (2007) 1365-1370. 
Taş, E., 2011. Bisküvi üretiminde bazı kabartıcı kombinasyonlarının bisküvinin kalitatif özelliklerine etkisi üzerine bir araştırma. Selçuk Üniversitesi Fen Bilimleri Enstitüsü Gıda Mühendisliği Anabilim Dalı Yüksek Lisans Tezi, Konya, Türkiye, $79 \mathrm{~s}$.

Tomar, O., Yıldırım, G., 2019. Kırmızı Pancarın Antimikrobiyal Etkisi (Beta vulgaris var. Cruenta Alef.) Bazı Gıda Kaynaklı Patojenler Üzerindeki Antimikrobiyal Etkisi. Türk Tarım Dergisi - Gıda Bilimi ve Teknolojisi, 7 (sp1): 54-60.

Turkut, G.M., Çakmak, H., Kumcuoğlu, S., Tavman, S., 2016. Effect of Quinoa Flour on Gluten-Free Bread Batter Rheology and Bread Quality. Journal of Cereal Science, 69,174-181.

Türksoy, S., Özkaya, B., 2006. Gluten ve çölyak hastalı̆̆ı, Türkiye 9. Gıda Kongresi 24-26 Mayıs 2006, Bolu.

Türksoy, S., Özkaya, B., 2011. Pumpkin and Carrot Pomace powders as a Source of Dietary Fiber and Their effects on Mixing properties of wheat Flour dough and Coockie Quality, Food Sci. Technol. Res.,17.6, 545-553.

Tüter, H., 2019. Chıa (Salvia Hispanica) Tohumu Kullanılarak Fonksiyonel Glutensiz Bisküvi Üretimi Ve Kalite Özelliklerinin Belirlenmesi. Manisa Celal Bayar Üniversitesi Fen Bilimleri Enstitüsü Gıda Mühendisliği Anabilim Dalı Yüksek Lisans Tezi, Manisa, Türkiye, $179 \mathrm{~s}$.

Villancacci, V., Ceppa, P., Tavani, E., Vindigni, C., Volta, U., 2011. Coeliac Disease: the Histology Report. Digestive and Liver Disease, 43, 385-395.

Wu, Q., Miano, Y.,, 2008. Mechanochemical Efects of Micronization on Enzymatic Hydrolysis of Corn Flour. Carbohydrate Polymers, 72, 398-402.

Yarpuz, D., 2011. Glutensiz Ekmek Üzerine Araștırmalar. Selçuk Üniversitesi, Fen Bilimleri Estitüsü, Yüksek Lisans Tezi, 44s, Konya. 